\title{
Analisis Kebutuhan Pelestarian Bahan Perpustakaan Tercetak
}

\author{
Endang Fatmawati \\ eenfat@yahoo.com
}

\begin{abstract}
This article discusses the needs analysis of library printed material preservation in the library. To provide a quality library materials and realize the library as a source of information for users, it takes the name of the preservation of library materials. Analysis survey of library material preservation needs is essential for conservation planning. This is based on the library's needs and the actions necessary to meet these conservation needs. Approaches that libraries can use to analyze the needs of library materials preservation are: public conservation planning surveys, special library material surveys, and library condition survey. The result of the proposed improvement of library materials as stated in the order of priority conservation needs analysis report and conservation policy. Planning related policies and procedures for preventive preservation activities need to be done to minimize damage to printed library materials.
\end{abstract}

Keywords: paper, curative conservation, preservation needs, policy.

\begin{abstract}
Abstrak
Artikel ini membahas mengenai analisis kebutuhan pelestarian bahan perpustakaan tercetak di perpustakaan. Untuk menyediakan bahan perpustakaan yang berkualitas dan mewujudkan perpustakaan sebagai sumber informasi bagi pemustaka, maka dibutuhkan yang namanya pelestarian bahan perpustakaan. Survei analisis kebutuhan pelestarian bahan perpustakaan sangat penting untuk perencanaan pelestarian. Hal ini didasarkan pada kebutuhan perpustakaan dan tindakan yang diperlukan
\end{abstract}


untuk memenuhi kebutuhan pelestarian tersebut. Pendekatan yang bisa digunakan oleh perpustakaan untuk menganalisis kebutuhan pelestarian bahan perpustakaan yaitu: survei perencanaan pelestarian umum, survei bahan perpustakaan khusus, dan survei kondisi bahan perpustakaan. Hasilnya diperoleh usulan perbaikan bahan perpustakaan yang tertuang dalam urutan prioritas laporan analisis kebutuhan pelestarian dan kebijakan pelestarian. Perencanaan terkait kebijakan dan prosedur untuk kegiatan pelestarian preventifperlu dilakukan untuk meminimalisir kerusakan bahan perpustakaan tercetak.

Kata kunci: kertas, konservasi kuratif, kebutuhan pelestarian, kebijakan.

\section{Pendahuluan}

Selain unsur manusia yang mengelola, maka sumber daya lain yang tidak kalah penting dari sebuah perpustakaan adalah bahan perpustakaan. Sekalipun sudah era digital, namun keberadaan bahan perpustakaan tercetak masih diperlukan juga. Hal inilah yang melatarbelakangi pentingnya melakukan kegiatan pelestarian bahan perpustakaan tercetak tersebut. Salah satu kegiatan yang penting pada awal kegiatan pelestarian bahan perpustakaan adalah mengidentifikasi kebutuhan dengan menentukan penilaian atau menganalisis terhadap berbagai faktor yang mempengaruhi pelestarian.

Survei analisis kebutuhan pelestarian bahan perpustakaan didasarkan pada kebutuhan perpustakaan dan tindakan yang diperlukan untuk memenuhi kebutuhan tersebut, misalnya survei kondisi lingkungan mencakup survei terhadap kondisi seluruh bangunan dimana koleksi disimpan. Perpustakaan merupakan sumber informasi yang merekam beragam informasi, melindungi dan melestarikan khasanah kekayaan budaya bangsa, pusat belajar sepanjang hayat, dan sebagai sebuah wadah yang diciptakan untuk tujuan mengelola pengetahuan. Begitu pentingnya bahan perpustakaan yang ada di masing-masing perpustakaan, maka perlu merencanakan pelestarian bahan perpustakaan. Semua itu dilakukan agar ilmu pengetahuan dari bahan perpustakaan bisa digunakan secara optimal dalam jangka waktu yang lama, dan bisa untuk diwariskan ke generasi penerus yang akan datang. 
Bahan perpustakaan (koleksi) di perpustakaan bukan hanya tercetak (berupa kertas), namun ada material fotografis (film, gambar hidup, mikrofilm, mikrofis, foto), kemudian optical disc (video disc, compact disc), maupun magnetic media (disket, kaset) dan lain sebagainya. Namun analisis kebutuhan pelestarian bahan perpustakaan yang dimaksud dalam konteks artikel ini saya batasi pada bahan perpustakaan tercetak, sehingga tujuannya adalah untuk menganalisis kebutuhan pelestarian bahan perpustakaan yang bermedia kertas.

\section{Pembahasan}

\section{Identifikasi Kebutuhan}

Bahan pustaka sering disebut juga dengan koleksi atau jika sesuai dengan payung hukum yang ada, maka istilahnya menjadi "bahan perpustakaan”. Dalam Undang-Undang RI Nomor 43 Tahun 2007 tentang Perpustakaan pada Bab I Pasal 1 butir 10, dijelaskan bahwa "Bahan perpustakaan adalah semua hasil karya tulis, karya cetak, dan/atau karya rekam”.

Orang yang bertugas melestarikan bahan perpustakaan biasa disebut dengan konservator (conservator). Pustakawan yang bekerjanya di bagian pelestarian juga bisa disebut dengan istilah konservator, yang artinya pustakawan tersebut bertanggung jawab atas pemeliharaan, pemugaran, dan perbaikan bahan perpustakaan yang rusak. Alasan perlunya dilakukan analisis kebutuhan pelestarian terlebih dahulu karena sebagai petunjuk dalam menentukan langkah pelestarian yang perlu diambil dan meningkatkan pengetahuan petugas konservator maupun pustakawan tentang bahan perpustakaan yang dimiliki.

Aspek dalam melestarikan bahan perpustakaan, adalah dengan memperhatikan kondisi fisik bahan perpustakaan, intensitas penggunaannya oleh pemustaka, faktor kelangkaan bahan perpustakaan, kemudian juga sisi ekonomis, nilai estetika, maupun mengandung nilai sejarah. Dengan demikian, yang dimaksud dengan analisis kebutuhan pelestarian bahan perpustakaan adalah cara-cara yang dilakukan oleh para konservator maupun pustakawan untuk mengidentifikasi, membuat prioritas, mengalokasikan 
sumber daya, serta menganalisis kebutuhan pelestarian bahan perpustakaan.

Faktor yang dianalisis tersebut meliputi aspek fisik perpustakaan berarti terkait dengan kondisi dimana bahan perpustakaan itu berada, sedangkan aspek organisasi berarti terkait dengan sistem kelembagaan di sebuah perpustakaan. Lebih jelasnya seperti Gambar 1 berikut:

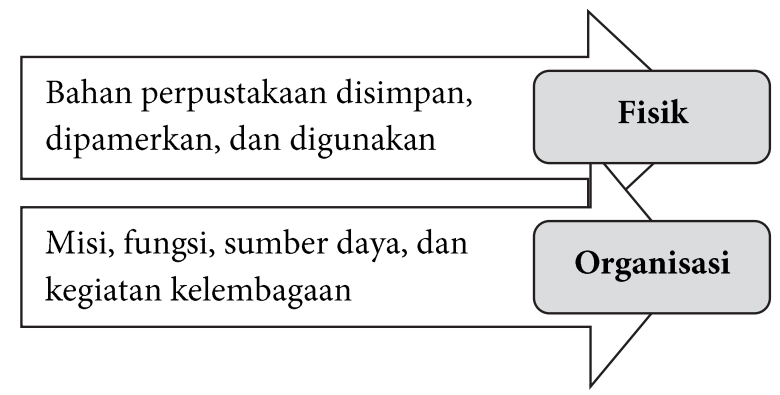

Gambar 1. Aspek Analisis Kebutuhan Pelestarian

Analisis kebutuhan pelestarian bahan perpustakaan dilakukan dengan mempertimbangkan kelembagaan perpustakaan dan kesesuaiannya dengan tujuan suatu perpustakaan, kebijakan mengumpulkan bahan perpustakaan dan sumber daya yang tersedia, maupun mempertimbangkan iklim sosial dan politik dimana perpustakaan tersebut berada. Tujuan dari analisis kebutuhan pelestarian bahan perpustakaan adalah untuk membantu sebuah perpustakaan untuk:

a. Mengidentifikasi kerusakan seluruh bahan perpustakaan tercetak;

b. Mengevaluasi kebijakan pelestarian, praktik dan kondisi dalam sebuah perpustakaan yang mempengaruhi pelestarian semua jenis bahan perpustakaan;

c. Mengidentifikasi kebutuhan pelestarian koleksi khusus;

d. Merekomendasikan tindakan untuk memenuhi kebutuhan pelestarian dan membuat prioritas tindakan yang direkomendasikan;

e. Memperbaiki keadaan umum semua bahan perpustakaan, apa yang dibutuhkan untuk memperbaiki keadaan itu dan bagaimana melestarikan koleksi jangka panjang. 
Sementara itu, fungsi dari analisis kebutuhan pelestarian bahan perpustakaan antara lain:

a. Sebagai petunjuk dalam menentukan langkah-langkah pelestarian bahan perpustakaan yang perlu diambil;

b. Meningkatkan pengetahuan konservator maupun pustakawan;

c. Memberikan pengalaman dan pelatihan pada konservator maupun pustakawan dalam penilaian masalah kebutuhan pelestarian bahan perpustakaan;

d. Mendorong kerja tim antara konservator dan pustakawan dalam melakukan perawatan bahan perpustakaan;

e. Sebagai rekam jejak dari apa yang telah dikerjakan, sehingga membantu dalam mengambil keputusan, dan mengetahui langkah apa yang sebaiknya dilakukan.

Beberapa komponen utama analisis kebutuhan pelestarian bahan perpustakaan meliputi: sarana fisik (gedung, bangunan, ruang penyimpanan koleksi); lingkungan (suhu/kelembaban); dan koleksi (kondisi, sejarah). Gedung melindungi bahan perpustakaan dari bagian luar, sehingga merupakan pertahanan pertama melawan pengaruh cuaca, polusi, dan air. Memeriksa gedung secara berkala dan pemeliharaan atap, dinding, saluran air merupakan investasi dalam melestarikan gedung perpustakaan. Jadi setiap gedung perpustakaan idealnya harus mempunyai jadwal tertulis pemeliharaan eksterior dan interior gedung.

\section{Survei Kondisi}

Pendekatan yang digunakan oleh perpustakaan untuk menganalisis kebutuhan pelestarian bahan perpustakaan, yaitu:

1. Survei perencanaan pelestarian secara umum

Yaitu survei secara menyeluruh yang mengarah pada laporan deskripsi berdasarkan hasil kuesioner dan wawancara dengan seluruh pihak yang bertanggung jawab atas pelestarian dan hal yang berhubungan dengan bahan perpustakaan dan bangunan. Tujuannya untuk mengidentifikasi 
kerusakan dan penyebab kerusakan bahan perpustakaan secara keseluruhan dan untuk membantu pelestarian dengan strategi pemeliharaan secara preventif.

2. Survei bahan perpustakaan khusus

Yaitu survei dengan metode stratifikasi yang ditujukan kepada perpustakaan yang berbeda-beda format, maupun dengan sistematik survei yang ditujukan pada bahan perpustakaan yang spesifikasi formatnya sama. Pustakawan yang bertindak sebagai konservator akan menganalisis bahan perpustakaan, membuat rekomendasi untuk perawatan termasuk tindakan pencegahan secara menyeluruh, dan usulan konservasi kuratif. Tujuannya untuk menentukan kebutuhan sumber daya dan dana yang akan digunakan dalam pelestarian.

3. Survei koleksi bahan perpustakaan

Yaitu survei yang memfokuskan pada bahan perpustakaan terpilih, sehingga lebih rinci daripada survei koleksi khusus. Caranya dengan pemeriksaan mendalam terhadap sekelompok bahan perpustakaan yang relatif sedikit dengan cara menganalisis jenis dan kerusakan bahan perpustakaan serta membuat usulan perbaikan.

Survei kondisi bahan perpustakaan dilakukan dengan memeriksa kondisi fisik bahan perpustakaan dan jenisnya, kemudian juga tingkat kerusakan yang terjadi, misalnya: kondisi kertas, kondisi jilidan, dan kondisi cover. Dari hasil survei ini akan diperoleh kondisi rusak yang harus secepatnya mendapat perawatan dan perbaikan, kondisi sedang yang perlu mendapat perhatian, serta kondisi baik yang harus dipelihara agar tidak menjadi rusak.

Analisis kebutuhan pelestarian bahan perpustakaan tumbuh dari survei kondisi bahan perpustakaan untuk mengatasi masalah kerusakan kertas. Analisis ini dilakukan dengan suatu instrumen melalui survei dalam rangka mengevaluasi kebijakan, kondisi bahan perpustakaannya, dan kondisi lingkungan yang mempengaruhi pelestarian. Metodologi survei dilakukan dengan kualitatif dan kuantitatif. 
Survei kuantitatif mencakup statistik dengan menarik sampel secara acak dan biasanya untuk menentukan kondisi koleksi, misalnya keasaman kertas. Survei kuantitatif juga bisa dengan menggunakan metodologi survei yang diadopsi dari Stanford University (1979) dengan kategori yang ditelaah yaitu sampul/cover buku, kondisi jilidan, dan kondisi kertas. Ketiga kategori tersebut dibagi ke dalam tiga penilaian kondisi ( $0=$ kondisi baik; $1=$ kondisi sedang; 2 = kondisi buruk). Kondisi baik berarti tidak memerlukan perbaikan. Kondisi sedang berarti membuktikan adanya kerusakan, memerlukan beberapa perhatian untuk perbaikan. Kondisi buruk berarti ada kerusakan berat sehingga tidak boleh digunakan atau dilayankan kepada pemustaka dan memerlukan perhatian atau perbaikan segera.

Penilaian dilakukan dengan berdasarkan pemeriksaan bahan perpustakaan satu persatu sehingga akan diperoleh jumlah dan persentasenya. Pengelompokan kategori tersebut dengan ciri-ciri sebagai berikut:

\begin{tabular}{|c|c|c|c|}
\hline & SAMPUL/COVER & JILIDAN & KERTAS \\
\hline 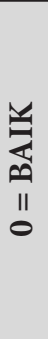 & $\begin{array}{l}\text { Sampul masih baik, tidak } \\
\text { robek, punggung tidak } \\
\text { robek, tidak ada halaman } \\
\text { yang hilang, punggung } \\
\text { buku terjilid dengan baik, } \\
\text { sudut-sudut buku tidak } \\
\text { robek, terlipat dan tidak } \\
\text { ada yang hilang }\end{array}$ & $\begin{array}{l}\text { Jahitan masih utuh, } \\
\text { halaman terjilid dengan } \\
\text { baik, tidak ada halaman } \\
\text { yang hilang, perekat/lem } \\
\text { masih baik }\end{array}$ & $\begin{array}{l}\text { Kertas tidak robek, tidak } \\
\text { keriput, tidak kotor, } \\
\text { tidak berwarna kuning } \\
\text { kecoklatan, tidak ada kertas } \\
\text { yang robek/patah pada } \\
\text { saat sudut kertas dilipat } \\
\text { perlahan, tidak ada kertas } \\
\text { yang jatuh bila dibalik }\end{array}$ \\
\hline 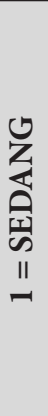 & $\begin{array}{l}\text { Sampul masih baik tapi } \\
\text { sudah ada tanda pecah- } \\
\text { pecah pada punggung } \\
\text { buku baik bagian dalam } \\
\text { maupun luar, sudut } \\
\text { sampul ada yang robek } \\
\text { atau melengkung tapi } \\
\text { belum ada yang terlepas, } \\
\text { punggung buku sudah } \\
\text { robek tetapi tidak hilang }\end{array}$ & $\begin{array}{l}\text { Benang jahitan sudah } \\
\text { mulai rapuh tapi tidak } \\
\text { sampai putus, halaman } \\
\text { sudah kelihatan longgar, } \\
\text { satu atau dua halaman } \\
\text { sudah mulai lepas, } \\
\text { perekat/lem sudah mulai } \\
\text { pecah-pecah }\end{array}$ & $\begin{array}{l}\text { Ada bagian kertas yang } \\
\text { robek atau ada sobekan } \\
\text { kertas yang hilang, } \\
\text { kelihatan kotor, ada tanda- } \\
\text { tanda kuning kecoklatan, } \\
\text { tidak ada potongan kertas } \\
\text { yang jatuh pada saat } \\
\text { dibalik, kertas tidak patah } \\
\text { atau robek saat sudut kertas } \\
\text { ditekan perlahan }\end{array}$ \\
\hline
\end{tabular}




\begin{tabular}{|c|c|c|c|}
\hline & SAMPUL/COVER & JILIDAN & KERTAS \\
\hline 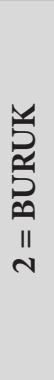 & $\begin{array}{l}\text { Sampul rusak berat, sudah } \\
\text { tidak menjilid dengan baik, } \\
\text { punggung buku sudah } \\
\text { pecah-pecah, sudut-sudut } \\
\text { sampul robek, terlepas dan } \\
\text { hilang, punggung buku } \\
\text { mengalami kerusakan } \\
\text { berat, terlepas dari buku } \\
\text { dan hilang }\end{array}$ & $\begin{array}{l}\text { Benang jahitan sudah } \\
\text { ada yang putus, halaman } \\
\text { sangat longgar dan lebih } \\
\text { dari tiga halaman sudah } \\
\text { terlepas, perekat/lem } \\
\text { sudah kering dan pecah- } \\
\text { pecah }\end{array}$ & $\begin{array}{l}\text { Kertas ada sobekan yang } \\
\text { hilang, patah, berlubang, } \\
\text { keriput, kelihatan } \\
\text { kotor, berwarna kuning } \\
\text { kecoklatan, ada potongan } \\
\text { kertas yang jatuh pada saat } \\
\text { dibalik, kertas jatuh pada } \\
\text { saat kertas dites dengan } \\
\text { cara dilipat }\end{array}$ \\
\hline
\end{tabular}

Sumber: Razak (2004: 69).

Sementara itu, survei kualitatif dilakukan untuk mengevaluasi segala hal yang berhubungan dengan kebijakan dan prosedur, seperti: kondisi bangunan dan kondisi lingkungan, kesiapan menghadapi bencana, kondisi ruang, kondisi bahan perpustakaan saat dialihmediakan, maupun kebutuhan ketika dilakukan penanganan konservasi. Dalam Razak (2004: 63) disebutkan bahwa survei kualitatif dilakukan untuk memperoleh data kondisi lingkungan pada tempat penyimpanan, yang meliputi: suhu, peralatan untuk mengukur, program monitoring, dan pengendalian kondisi lingkungan tempat penyimpanan bahan perpustakaan.

Rencana dan strategi pelestarian yang akan diambil pustakawan dan konservator memerlukan analisis kebutuhan pelestarian untuk mengidentifikasi seberapa besar kerusakan bahan perpustakaan, baik dari dalam bahan perpustakaan itu sendiri maupun pengaruh kerusakan dari luar. Selain itu, juga memutuskan kebutuhan yang menjadi prioritas sebagai upaya meminimalkan timbulnya kerusakan bahan perpustakaan. Selanjutnya kriteria tepat dan tidaknya hasil analisis kebutuhan pelestarian bahan perpustakaan ditentukan oleh faktor pengetahuan (pendidikan dan penalaran), keahlian (pengalaman dan ketrampilan), sumber daya yang tersedia, serta kerjasama dan analisis untuk sampai pada usulan perbaikan.

Kertas bersifat "higroskopik" yang mudah menyerap dan melepaskan uap air dari lingkungan sekitarnya. Begitu pula sinar ultraviolet pada cahaya matahari dapat merusak kertas, karena menyebabkan serat kertas menjadi 
rapuh. Pada dasarnya semua cahaya mempercepat kerusakan kertas karena energi yang dikeluarkan mengakibatkan reaksi kimia yang merusak kertas. Intinya lingkungan penyimpanan yang buruk mengurangi umur kehidupan kertas dan bahan lainnya yang terkait.

Ruang perpustakaan dengan jendela terbuka, menyebabkan masuknya gas pencemar atau polutan yang menyebabkan rapuhnya kertas. Hal ini seperti sulfur dioksida dan nitrogen oksida (yang biasanya dihasilkan dari mobil dan industri), peroksida dan reaksi kimia katalis ozon, yang akan mengarah pada pembentukan asam kertas. Belum lagi paparan partikulat dan polutan gas terhadap bahan perpustakaan. Kertas menjadi bersifat asam apabila $\mathrm{pH}$ kertas berubah menjadi rendah karena pengaruh gas polutan. Solusi cerdasnya adalah dengan menyedot debu secara rutin untuk melawan partikel polutan tersebut.

Kotoran apapun jenisnya termasuk debu akan mengurangi nilai estetika pada bahan perpustakaan tercetak. Debu dapat menyebabkan kertas menjadi asam karena debu biasanya bercampur dengan pencemar udara lainnya seperti hasil pembakaran bahan bakar minyak bumi sehingga menyebabkan kerusakan bahan perpustakaan. Jika bahan perpustakaan yang terkena debu kemudian terkena air dan udara lembab maka akan menimbulkan noda pada bahan perpustakaan tersebut.

Hemat saya, membersihkan debu pada bahan perpustakaan ini termasuk dalam kegiatan konservasi kuratif karena dilakukan untuk menyelamatkan kondisi fisik bahan perpustakaan agar terhindar dari kerusakan lebih lanjut. Konservasi merupakan bagian dari kegiatan pelestarian. Hal ini seperti yang dikonsepkan oleh Harvey (1993) bahwa pelestarian konsepnya lebih luas dan salah satunya mencakup konservasi tersebut.

Adanya debu, kotoran, ketidakterawatan, dan makanan yang ada di sekitar bahan perpustakaan, akan menarik datangnya serangga dan hewan pengerat. Pustakawan perlu mewaspadai dan siaga jika di sekitar bahan perpustakaan ada sampah, maupun potongan tubuh serangga, kecoa, dan sejenisnya. Pemecahannya adalah dengan membersihkan secara rutin 
dan hati-hati jika mengepel lantai dengan media basah di dekat bahan perpustakaan pada rak-rak yang lebih rendah. Sebaiknya menggunakan vakum yang dilengkapi dengan "partikel udara efisiensi tinggi (High Efficiency Particulate Air - HEPA filter)" untuk membersihkan bahan perpustakaan tercetak tersebut.

Jadi analisis kebutuhan pelestarian dilakukan dengan mempertimbangkan kondisi bahan perpustakaan dan potensi masalahnya, sehingga memerlukan survei kondisi bahan perpustakaan. Survei kondisi lingkungan untuk mengidentifikasi tindakan preventif yang perlu diambil untuk menyelamatkan bahan perpustakaan dari faktor potensial yang merusak. Selain itu, untuk mengidentifikasi langkah-langkah penanganan konservasi, termasuk penanganan pada setiap bahan perpustakaan, perkiraan biaya yang diperlukan dalam penanganan konservasi. Survei kondisi lingkungan tersebut meliputi hal-hal seperti pada Gambar 2 berikut:

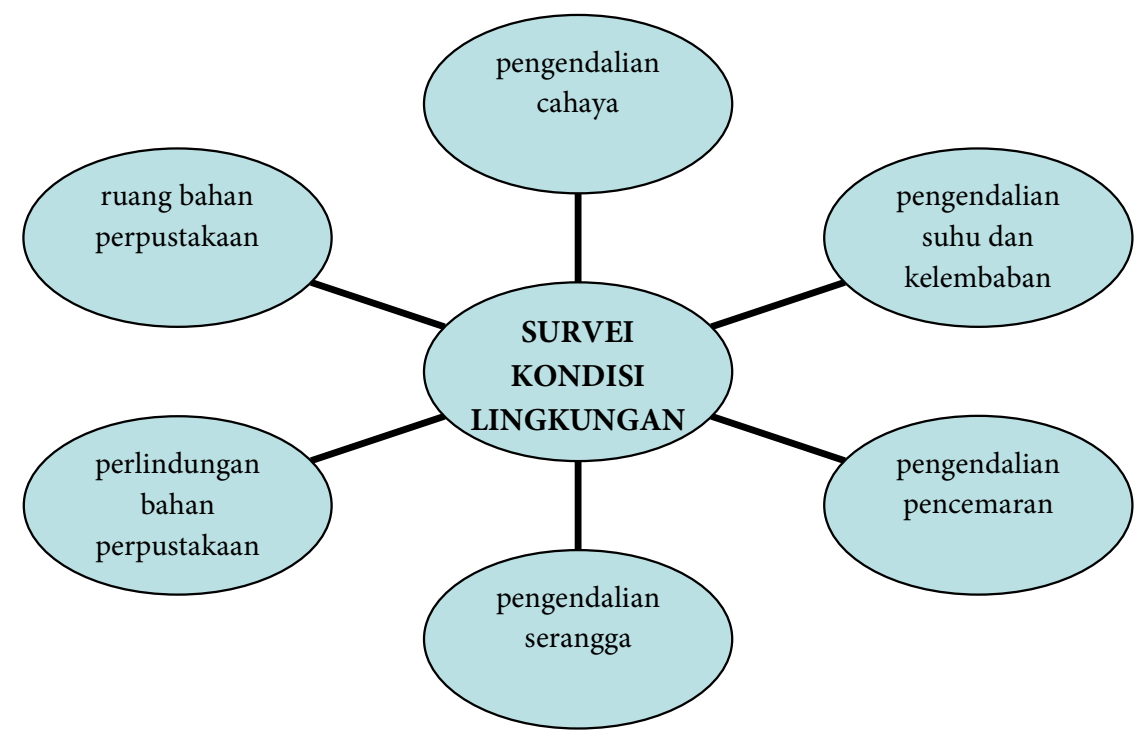

Gambar 2. Survei Kondisi Lingkungan

Untuk survei fasilitas perpustakaan meliputi bagaimana kondisi lingkungan tempat penyimpanan bahan perpustakaan, ruang baca, dan ruang 
lainnya. Kondisi lingkungan tersebut dipengaruhi oleh intensitas cahaya dan kandungan ultra violet dalam cahaya, suhu/kelembaban, polutan, serangga, kebersihan ruangan, keamanan gedung, perlindungan dari bahaya kebakaran, banjir, vandalisme dan lain sebagainya.

Kerusakan yang disebabkan oleh udara lembab dikelompokkan ke dalam faktor eksternal. Kelembaban merupakan katalisator yang menyebabkan reaksi kimia dalam kertas yang mengarah pada pembentukan asam. Proses untuk menghilangkan asam pada kertas tersebut dikenal dengan nama "deasidifikasi". Kelembaban yang berlebihan menyebabkan jamur dan foxing, tetapi kebalikannya jika terlalu rendah justru mengeringkan dan merapuhkan kertas.

Foxing tersebut berupa noda kuning kecoklatan seperti noda karat yang disebabkan oleh partikel besi, jamur maupun udara lembab. Lembab biasanya terjadi pada bahan perpustakaan yang disimpannya tidak di rak terbuka, melainkan pada tempat tertutup (seperti laci, lemari). Oleh karena itu, untuk menjaga agar temperatur dan kelembaban udara selalu kering maka bisa menggunakan "silica gel". Jadi kelembaban memang menjadi masalah tersendiri. Terkait kelembaban, maka kelembaban relatif yang disarankan untuk perpustakaan adalah 30-50\% RH, fluktuasi harian maksimum + /- 3\% $\mathrm{RH}$, dan maksimum bulanan 3\%. Selanjutnya suhu dan kelembaban yang dianjurkan untuk pelestarian bahan perpustakaan kertas berkisar antara $20^{\circ}-24^{\circ} \mathrm{C}$ dan $45 \%$ - $60 \% \mathrm{RH}$.

Beberapa aspek bahan perpustakaan yang perlu diidentifikasi, misalnya: kondisi bahan perpustakaan secara keseluruhan, ketepatan kondisi lingkungannya, bahan perpustakaan yang paling rusak dan segera membutuhkan penanganan konservasi, terkait dengan jenis, bahan, maupun ukuran bahan perpustakaannya. Kerusakan bahan perpustakaan bisa dikategorikan secara fisik, gangguan biologi, dan kimiawi seperti yang terlihat pada Gambar 3 berikut: 


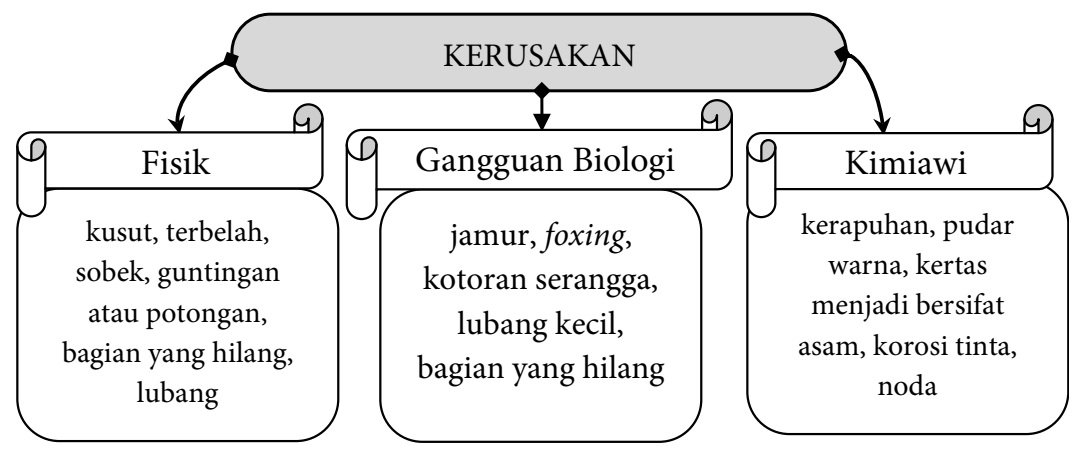

Gambar 3. Jenis Kerusakan

Hasil survei yang telah dilakukan kemudian disimpulkan, dibandingkan dan disintesa sehingga menghasilkan data untuk menentukan rencana pelestarian. Mengerti kebutuhan bahan perpustakaan adalah langkah kunci dalam memecahkan masalah yang telah diidentifikasi, sementara data survei menyediakan dokumen yang meyakinkan untuk menentukan rencana pelestarian. Usulan prioritas untuk rencana perbaikan bahan perpustakaan bisa mencakup jangka pendek (1 tahun), jangka menengah (3 tahun), dan jangka panjang (5 tahun).

Apabila data yang dihasilkan berupa deskriptif tentang jenis bahan perpustakaan, ruang penyimpanan, jenis kerusakan (patah, rusak) maka analisisnya dengan membuat daftar sederhana berupa daftar jenis bahan perpustakaan, ruang penyimpanan, dan jenis kerusakan. Namun apabila datanya kuantitatif (jumlah koleksi, jenis kerusakan bahan perpustakaan pada tingkat yang berbeda-beda), maka analisisnya menggunakan metode statistik sederhana dengan cara mentabulasikan tingkat kerusakan dan menghitungnya dengan persentase, mengkorelasikan antara jenis kerusakan dengan tingkat kerusakan bahan perpustakaan dan lain sebagainya.

\section{Prioritas kebutuhan}

Pustakawan dan konservator harus bijak dalam menentukan skala prioritas konservasi bahan perpustakaan. Pustakawan menentukan prioritas berdasarkan "nilai" dari setiap bahan perpustakaan, sedangkan konservator 
menentukan prioritas berdasarkan "kondisi kerusakan" dari bahan perpustakaan. Diantara pustakawan dan konservator harus bekerja sama dalam menentukan dan memutuskan terkait skala prioritas, metode, bahan serta prosedur kerja yang akan diterapkan. Hal ini sangat penting dalam rangka untuk menghindari kesalahan atau kekurangtepatan penanganan yang akan dilakukan.

Dalam Wirayati, Ayu, Riyadi (2014: 8-9) dijelaskan bahwa faktor yang berpengaruh dalam menentukan prioritas adalah jenis bahan perpustakaan dengan penggunaan terus-menerus sehingga bahan perpustakaan menjadi rusak dan membutuhkan perhatian yang serius. Selain itu, faktor nilai (value) yang terkandung dalam bahan perpustakaan itu sendiri, diantaranya adalah nilai ekonomis (mahal), nilai sejarah, nilai estetika, nilai dokumenter (berhubungan) dan nilai gunanya.

Identifikasi bahan perpustakaan secara lengkap dan sangat terperinci/ detail perlu dilakukan sebelum melakukan pekerjaan konservasi. Hal ini untuk memperkecil akibat yang ditimbulkan jika kemungkinan terjadi bencana. Analisis yang dilakukan dibagi menjadi 3 (tiga), yaitu:

1. Analisis struktur, yaitu melakukan pengujian pada sebagian kecil dari dokumen untuk diuji dengan beberapa bahan kimia. Analisis struktur dilakukan dengan destruktif dan non destruktif. Analisis dengan destruktif berarti menyobek atau mengambil sebagian kecil dari dokumen untuk dilakukan analisis kandungan unsur yang membentuk kertas. Sementara itu, analisis non destruktif dilakukannya dengan tanpa merusak dokumen yaitu dengan menggunakan instrumentasi, contohnya dengan melakukan analisis kertas di bawah mikroskop elektron.

2. Analisis fisik, mencakup pengujian kelunturan tinta, arah serat, ketebalan bahan yang dipakai untuk konservasi, serta kelenturan. Untuk menentukan arah serat dengan merobek sebagian bahan kertas, dan apabila sulit dirobek berarti bahan tersebut berlawanan dengan arah serat sehingga akan nampak kertas berkerut atau menggulung. Untuk mengukur ketebalan dilakukan dengan menggunakan alat "mikrometer", 
sedangkan untuk menganalisis berat bahan dengan menimbang bahan perpustakaan menggunakan timbangan digital.

3. Analisis kimia, meliputi: uji keasaman kertas ( $\mathrm{pH})$, uji tinta, dan uji perekat.

a. Tes Keasaman

Asam yang berasal dalam kertas berasal dari kertas itu sendiri. Sebenarnya asam bisa melekat pada kertas selama waktu pembuatan, adanya gas asam dan polusi udara maupun salah penanganan. Menurut Harvey (1993: 60) bahwa keasaman pada kertas akan meningkat dengan ditambahnya bahan pemutih, penggunaan tinta, polusi udara, dan perpindahan asam pada kertas.

Asam adalah hasil samping dari penguraian lignin dan serat selulosa. Kekuatan kadar asam dari kertas adalah dengan mengukur $\mathrm{pH}$. Sebelum dan sesudah konservasi maka harus diukur nilai pHnya. Nilai pH berkisar antara dari 0 sampai 14 dengan formula sifatnya seperti Gambar 4 berikut:

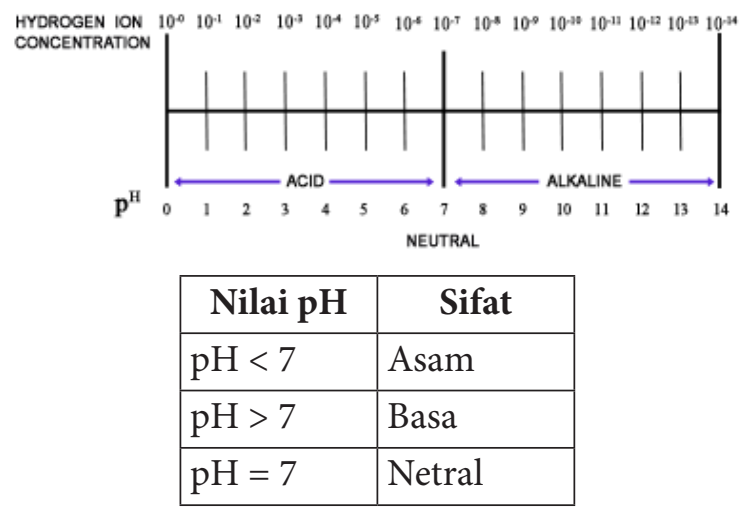

Gambar 4. Tabel dan Formula Sifat $\mathrm{pH}$

Alat untuk mengukur nilai $\mathrm{pH}$ tersebut misalnya dengan menggunakan kertas lakmus, $\mathrm{pH}$ pen, indikator universal ( $\mathrm{pH}$ strip), dan $\mathrm{pH}$ meter. Cara yang sering digunakan adalah dengan mengukur $\mathrm{pH}$ kertas dengan menggunakan $\mathrm{pH}$ Strip. Caranya kertas kertas pada 
ujung halaman dibasahi dengan air sehingga kertas menjadi basah, lalu $\mathrm{pH}$ strip ditempelkan pada kertas yang sudah basah, kemudian menutupnya dengan plastik lalu ditekan-tekan $+/$ - 5 menit. Lalu cara membaca hasilnya dengan mencocokkan warna yang sesuai dengan tabel warna $\mathrm{pH}$ dari 0 sampai dengan 14 (lihat Gambar 4).

Selanjutnya untuk mengukur keasaman dan kebasaan dengan menggunakan satuan $\mathrm{pH}$ (potensial hidrogen). Untuk contoh alatalatnya seperti pada Gambar 5 berikut:
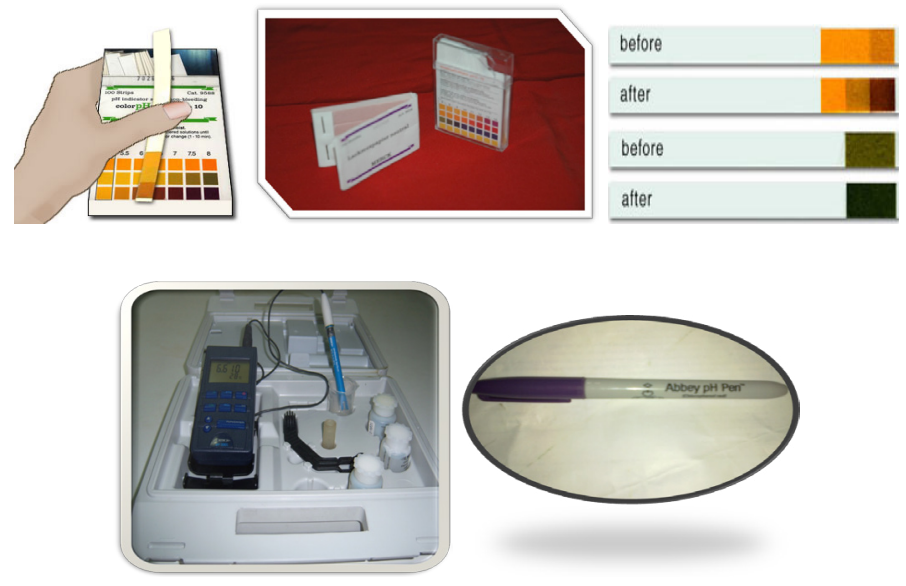

Gambar 5. Alat Untuk Mengukur pH

Sumber gambar: Ayu (2017)

b. Tes Tinta

Tinta adalah suatu cairan yang mengandung warna atau bahan pewarna yang tersuspensi. Tinta adalah setiap zat yang digunakan untuk menulis, mencetak atau mewarnai dengan menggunakan peralatan dan teknik yang sesuai. Tinta memiliki komponen dasar seperti:

1. Bahan pewarna yang mewarnai tinta;

2. Pelarut yaitu media dimana warna terlarut;

3. Zat pengikat yang menahan dan mengikat partikel warna; 
4. Zat kimia untuk tinta tidak luntur dan dapat menggantikan zat pengikat (mordant).

Jenis tintanya seperti tinta karbon, tinta iron gall, dan tinta sintetis. Tinta karbon diperoleh dari pembakaran bahan organik yang terdispersi di dalam air dan diikat oleh zat perekat. Tinta karbon adalah bahan stabil yang tidak terpengaruh cahaya atau zat kimia. Hanya saja masalahnya naskah yang ditulis dengan tinta karbon, warnanya dapat hilang apabila terkena gesekan atau digosok.

Tinta yang menyebabkan terjadinya korosi tinta pada kertas adalah tinta iron gall. Untuk jenis tinta iron gall ini, warna tinta diperoleh dari logam yang asam, dengan komponen asam tannic, ferro sulfat, logwood, gum arabik dan air. Oleh karena tinta iron gall mengandung logwood maka menjadi rentan terhadap cahaya, sehingga memudarkan warna tinta dan memutuskan zat pengikat tinta. Selanjutnya adanya asam tannic dan ferro sulfat akan menyebabkan terjadinya "korosi tinta", yaitu proses kerusakan kertas yang disebabkan oleh tinta iron gall sebagai hasil reaksi hidrolis katalis asam dan oksidasi katalis besi sehingga tinta menjadi terbakar dan kertas menjadi rusak karena tinta. Korosi tinta tersebut menyebabkan kertas menjadi terbakar karena disebabkan oleh tinta yang asam.

Tinta sintetis merupakan tinta modern yang mengandung aniline, seperti yang terdapat pada spidol, ballpoin, dan pulpen parker. Kelompok dari tinta sintetis yaitu: tinta padat (krayon, pastel); tinta berbasis air yang menggunakan air sebagai pelarut; tinta berbasis minyak yang warna tintanya berbeda dengan warna tinta yang terlarut dalam air; dan tinta akrilik yaitu tinta paling modern yang memiliki zat pengikat sistetis yaitu senyawa polyvinol dan akrilik. Minyak yang digunakan sebagai pelarut tinta pada tinta berbasis minyak adalah minyak biji rami atau minyak walnut.

Cara untuk mengetes kelarutan tinta terhadap air dapat dilakukan dengan cara sederhana yaitu dengan kapas atau kertas penyerap (blotting paper) basah pada tulisan yang berisi tinta yang akan diuji pada sudut 
halaman. Selanjutnya melapisi bagian bawah kertas yang akan diuji dengan plastik, sehingga air tidak tembus ke halaman berikutnya. Perlu diperhatikan juga bahwa daerah yang basah setelah mengetes tinta harus selalu diolesi dengan "etil alkohol" untuk mencegah pembentukan noda air. Untuk mengujinya adalah apabila tidak ada warna tinta yang menempel pada kapas basah atau kertas penyerap tersebut, maka dapat disimpulkan bahwa tinta yang diuji tersebut tidak luntur.

c. Tes Perekat

Perekat kertas ada yang natural dan sintetis. Perekat natural berasal dari tumbuhan dan binatang, namun kelemahannya adalah sangat disukai binatang dan mikro organisme, serta kurang stabil. Dikatakan kurang stabil misalnya saat temperatur atau kelembaban yang tinggi akan menjadi kehilangan fleksibilitas, mengubah perekat menjadi butiran yang berpengaruh terhadap kertas, melemahkan daya rekat, maupun menimbulkan noda pada kertas.

Perekat yang baik adalah jenis gelatin dan fish glue. Perekat sintetis bersifat thermostabil dan thermoplastic yang resisten terhadap panas tertentu, kemudian juga tidak bisa dikembalikan ke bentuk semula dengan jenis pelarut apapun. Oleh karena itu, jenis perekat sintetis tidak direkomendasikan untuk konservasi, namun lebih cocok jika digunakan untuk menjilid (binding).

Untuk langkah pendokumentasian bahan perpustakaan adalah dengan pembuatan data bibliografis, pencatatan kondisi fisik pada form survei kondisi, pembuatan foto, kemudian mengentri data pada pangkalan data. Selanjutnya pembersihan adalah sebagai upaya menghilangkan kotoran yang melekat pada kertas sehingga mengurangi keindahan dari penampilan fisik bahan perpustakaan. Pembersihan bisa dilakukan secara mekanik (vacuum cleaner, kuas, karet penghapus), dan secara kimiawi dengan pelarut organik. Vacuum cleaner dengan menyedot debu yang menempel pada kertas, kemudian kuas dengan cara membersihkannya secara searah, dan untuk karet penghapus bisa langsung digunakan pada kertas yang kotor atau jika 
kotor sekali maka karet penghapus diparut dahulu baru kemudian parutan karet penghapus digunakan untuk menghapus.

Kertas yang harus dibersihkan dengan cara kimiawi misalnya adanya noda yang disebabkan oleh partikel padat seperti tanah dan lumpur, kemudian karena terkena minyak, tinta yang luntur, maupun tetesan air. Begitu juga dengan selotip yang menyebabkan noda coklat serta warna kertas kuning kecoklatan, maka selotip bisa dilepas dengan pelarut organik atau taking iron. Selanjutnya untuk menghilangkan selotip yang merekat pada kertas adalah dengan trichlorethan, benzene, maupun aseton.

Dalam kegiatan menganalisis bahan perpustakaan tercetak, pustakawan maupun konservator perlu melakukan "paginasi”. Arti dari paginasi adalah dengan memberi nomor ulang pada bahan perpustakaan terjilid menggunakan pensil lunak 2B. Jadi sebelum bahan perpustakaan terjilid tersebut dibongkar, maka perlu dilakukan pemberian nomor pada sudut atas atau sudut bawah dengan angka kecil. Hal ini karena kadangkala ada lampiran, sisipan, gambar dan dokumen penting yang lainnya tanpa nomor halaman, kemudian terkadang juga ada halaman yang hilang atau tidak berurutan.

\section{Kebijakan}

Tujuan pelestarian bahan perpustakaan tiadalain untuk menyelamatkan nilai informasi dan menyelamatkan fisik dokumennya. Hal ini senada dengan yang dikatakan oleh Dureau dan Clements (1986) bahwa tujuan pelestarian yaitu: melestarikan kandungan informasi ilmiah yang direkam dan dialihkan pada media lain, maupun melestarikan bentuk fisik asli bahan perpustakaan sehingga dapat digunakan dalam bentuk seutuh mungkin.

Kebijakan untuk melakukan analisis kebutuhan pelestarian bahan perpustakaan hendaknya menjadi bagian integral dari misi perpustakaan. Lebih utamanya prioritas untuk pengidentifikasian dan penyelamatan bahan perpustakaan yang tidak dapat digantikan. Hal ini terkait arsip vital, koleksi sejarah, koleksi naskah dan yang lainnya. Dalam rangka mewujudkan 
program pelestarian, maka membutuhkan kebijakan yang solutif berbasis dari hasil analisis kebutuhan pelestarian bahan perpustakaan yang telah dilakukan.

Untuk perpustakaan besar yang jenis bahan perpustakaannya banyak dan memiliki koleksi langka (seperti halnya di Perpustakaan Nasional RI), maka urutan prioritas analisis kebutuhan pelestarian bahan perpustakaan yang diselamatkan dimulai dari naskah nusantara dan terakhir baru koleksi deposit. Lebih jelasnya seperti pada Gambar 6 berikut:

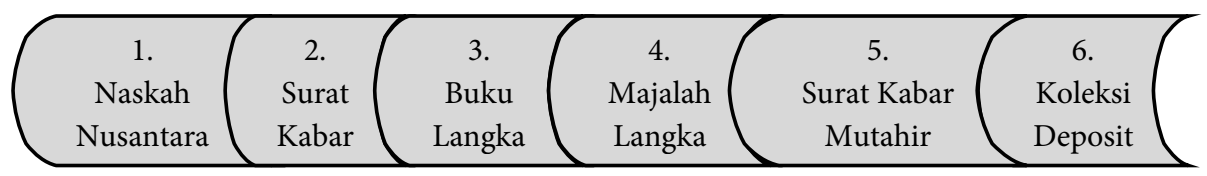

Gambar 6. Prioritas Kebutuhan

Program pelestarian bahan perpustakaan bukanlah hal yang mudah, namun memerlukan koordinasi dari unsur pimpinan sampai dengan staf perpustakaan. Semuanya perlu menumbuhkan kesadaran rasa memiliki dan senantiasa melestarikan agar dalam praktiknya menjadi efektif. Suatu kebijakan pelestarian bahan perpustakaan hendaknya dikembangkan dari waktu ke waktu sebagai kegiatan pelestarian yang sistematis.

Bagi perpustakaan yang tidak memiliki bagian preservasi, hal yang terjadi jika ada koleksi yang rusak sehingga tidak layak lagi untuk dilayankan, biasanya koleksi langsung dipindahkan dari ruang layanan ke gudang tempat buku rusak. Apabila demikian maka akan terjadi penumpukan di gudang dan justru semakin memperparah kerusakan. Belum lagi belum adanya kebijakan pelestarian bahan perpustakaan, rendahnya kesadaran dan tanggung jawab pustakawan, maupun pola pikir pimpinan lembaga yang belum memahami esensi perpustakaan, akan semakin memperburuk keadaan bahan perpustakaan. Jika demikian maka korelasinya akan berdampak pada tingginya volume kerusakan bahan perpustakaan, sehingga kuantitas bahan perpustakaan yang rusak semakin menumpuk dan semakin parah di gudang perpustakaan. 
Sebuah kebijakan pelestarian tersebut menyediakan pedoman tertulis untuk melaksanakan kegiatan pelestarian sebagai bagian dari kegiatan perawatan bahan perpustakaan sehari-hari. Suatu hal yang penting yang perlu diperhatikan adalah perlunya prioritas dalam mengambil keputusan pelestarian bahan perpustakaan. Alasannya tiada lain karena biasanya sumber daya untuk pelestarian tidak sama dengan jumlah kebutuhan untuk perawatan bahan perpustakaan. Artinya bisa dikatakan bahwa jumlah tenaga pelestari tidak sebanding (lebih kecil) dengan jumlah bahan perpustakaan yang rusak.

Begitu pula yang namanya laju kerusakan bahan perpustakaan tentu jauh lebih cepat apabila dibandingkan dengan laju penanganan bahan perpustakaannya. Penanganan dalam tataran ini maksudnya untuk pemeliharaan, perawatan, dan perbaikan bahan perpustakaan yang dimiliki. Kebijakan yang jelas dapat diterapkan secara menyeluruh dalam pelestarian preventif untuk memperpanjang daya guna bahan perpustakaan.

Dengan demikian, kebijakan dan prosedur untuk kegiatan pelestarian preventif perlu direncanakan. Hal ini meliputi banyak hal, seperti: keamanan bahan perpustakaan, mengontrol pemustaka yang menggunakan bahan perpustakaan, menggunakan sesuai pedoman dan standar pelestarian, mengolah dengan menggunakan teknik yang tidak merusak bahan perpustakaan, melakukan teknik penjilidan berkualitas, memantau lingkungan, menyimpan koleksi menurut pedoman pelestarian, maupun memelihara catatan tindakan konservasi.

\section{Penutup}

Analisis kebutuhan pelestarian bahan perpustakaan tercetak digunakan untuk menilai kebutuhan pelestarian di sebuah perpustakaan. Analisis kebutuhan pelestarian bahan perpustakaan dilakukan dengan mempertimbangkan kondisi bahan perpustakaan tercetak pada saat ini dan mengidentifikasi potensi masalah yang ada. Agar menghasilkan analisis yang lengkap maka memerlukan survei kondisi bahan perpustakaan yang lengkap pula. Survei menjadi langkah awal yang sistematis untuk melakukan 
perencanaan pelestarian bahan perpustakaan. Semua informasi hasil analisis kebutuhan pelestarian bahan perpustakaan tercetak diberikan kepada pimpinan, dalam bentuk laporan survei secara formal dan ditulis dalam bahasa yang jelas. Terkait dengan angka kedit, maka bagi pustakawan hal ini bisa menjadi ladang perolehan angka kredit dalam bentuk beragam kegiatan pelestarian bahan perpustakaan (misalnya melakukan pelestarian fisik koleksi perpustakaan). Hal yang perlu diingat bahwa dalam penyusunan perencanaan pelestarian harus memperhitungkan nilai bahan perpustakaan, kegunaan bagi pemustaka, risiko kerusakan yang terjadi pada bahan perpustakaan, maupun memerlukan kebijakan pelestarian sebagai pedoman dalam penyusunannya.

\section{Daftar Pustaka}

Ayu, Ellis Sekar. 2017. Analisis Kebutuhan Pelestarian Bahan Perpustakaan. Slide makalah disampaikan dalam Diklat Pelestarian Bahan Pustaka. Hotel Ibis Harmoni Jakarta, tanggal 22-23 Maret 2017.

Dureau, Jeanne-Marie and Clements, D.W.G. 1986. "Principles for The Preservation and Conservation of Library Materials". IFLA Professional Reports, No. 8. The Hague: IFLA Section on Conservation.

Harvey, Ross. 1993. Preservation in Libraries: Principles, Strategies and Practices for Librarians. London: Bowker-Saur.

Razak, Muhammadin. 2004. "Studi Tentang Pelestarian Manuskrip Nusantara di Perpustakaan Nasinal RI”. Tesis. Jakarta: FIB UI.

Undang-Undang Republik Indonesia Nomor 43 Tahun 2007 tentang Perpustakaan.

Wirayati, M. A., Ellis Sekar Ayu, Aris Riyadi. 2014. Pedoman Teknis Pelestarian Bahan Pustaka (Konservasi Kuratif Bahan Perpustakaan Media Kertas). Jakarta: Pusat Preservasi Perpustakaan Nasional RI. 